\title{
REGIONS OF DISCORD: ANALYZING SUBNATIONAL INFLUENCES ON CHILE'S FOREIGN TRADE AND INVESTMENT POLICIES TOWARDS THE USA DURING CRITICAL EVENTS
}

\section{Rodolfo Disi Pavlic ${ }^{1}$}

What role do subnational politics play in Chilean foreign trade and investment policies? Scholars have proposed several theories to explain the influence of domestic politics in the case of great powers' foreign policies (Gourevitch I986, Snyder I99I, Trubowitz I998; 20II); in the case of smaller and developing states, they have largely argued that foreign policymaking is primarily a function of international variables (Katzenstein I985). This argument is at odds, however, with the claim that international relations theories are inadequate to explain their behavior (Neuman 1998). Indeed, although most foreign policy outcomes are partly caused by a certain international context, it is overly simplistic to assume that foreign policy in developing countries is solely a function of changes in the international system.

In recent years, scholars have begun to analyze Latin American international relations and foreign policy more systematically and comparatively (Domínguez and Fernández de Castro 2010, Gardini and Lambert 20II, Mora and Hey 2003, Pastor 200I, Russell and Tokatlian 20II, Schoultz I998, Tulchin and Espach 200I). These various works have addressed several topics, at times quite successfully, and some have formulated several theoretical arguments that contribute to our understanding of foreign policymaking in Latin America. However, these contributions tend to share three shortcomings. First, these works are largely descriptive or issue-oriented and lack theoretical underpinnings; second, those that are theoreticallyoriented analyze hemispheric relationships from a US viewpoint; finally, most works focusing on changes in the international system pay less attention to

I Assistant Professor at the Department of Sociology and Political Science, Temuco Catholic University, Chile. PH.D. in Government, University of Texas at Austin (20I7). B.A. in Political Science, University of Notre Dame (20II). E-,mail: rdisi@uct.cl 
national and subnational factors within the Latin American states.

Chile's history of trade and foreign investment with the United States provides several critical examples and remarkable variation. In the past half century, Chile went from an Import Substitution Industrialization (ISI) economic model and the nationalization of US companies to liberalization and free trade. This process culminated in the 2004 United States-Chile Free Trade Agreement (FTA). Chile also shows an important degree of internal political change during this period. Indeed, the country experienced the breakdown of democracy, military dictatorship, and the return to competitive politics in the past forty years. What explains this broad range of trade and investment policy stances toward the USA?

As with the study of Latin American foreign policy in general, most studies provide international- and dyad-level accounts of changes in Chilean foreign policy. Changes in the international political economy (Wilhelmy I979), the balance of great powers (Álamos I999, Wilhelmy I979), regional rivalries (Colacrai and Lorenzini 2005, Álamos 1999, Wilhelmy 1979) are some of the most common explanations. The few domestic-level explanations tend to focus on variables like party and ideological conflicts (Mares and Rojas Aravena 200I, Wilhelmy and Durán 2003; Leight 2008), the role of economic elites (Oyarzún 2013, Baeza and López 2015), and the interaction of social and political actors and institutions (Porras 2003) ${ }^{2}$. Finally, those that analyze Chile's foreign policy comparatively also emphasize the importance of the country's democratic tradition and regime characteristics (Borges 20I7, Colacrai and Lorenzini 2005, Wilhelmy I979; Agüero 2005). These variables are important to understand the Chilean case and, more important, they consider its domestic politics and regime transitions in the past fifty years.

These variables, however, seem to be less useful in explaining critical events in USA-Chile relations. In democratic periods, the unanimous vote to nationalize US mining companies in I97I, and the near-universal ratification of the USA-Chile FTA challenge the importance of party and ideological differences ${ }^{3}$. Important measures taken during the Allende administration like state-ownership of copper companies persisted after 1973, and policies enacted during the Pinochet dictatorship that survived the transition to democracy in I990 - such as trade liberalization - also blur the distinction

\footnotetext{
2 Baeza and López (2015) and Leight (2008) consider the rural-divide as factor that influenced the ratification process of the USA-Chile FTA but focus on the role political parties and economic and political elites and played in the process.

3 Several prominent right-wing politicians even advocated against the FTA. As Leight (2008, 226) explains, "[t]he blatant protectionism, verging on outright populism, from the historically neoliberal right, was a rarity in post- I990 Chilean politics.”
} 
between democratic and authoritarian foreign policy. None of these variables can, therefore, fully explain the country's policy evolution.

In order to explain these outcomes, this paper examines several moments that shaped Chile's trade and foreign investment policies towards the US. These critical events occurred between I965 and 2005, and include the I967 Agrarian Land Reform; the so-called "Chileanization" (I969) and nationalization (I97I) of the copper industry; the reopening of the mining sector to foreign mining companies and the undoing of the Agrarian Reform (I974-I983); the USA-Chile FTA (2004); and the "Royalty" tax on private mining companies (2005). These rare events are chosen because they constitute "critical junctures" (R. B. Collier and Collier 2002) with "substantial and relatively quick change in an independent or dependent variable of theoretical interest" (Gerring 2004, 35I).

The study uses evidence from statements and actions of members of Congress (I965-1973; I990-2005) and the government junta (I973-I990), as well as from secondary sources. This research strategy, which allows for variation in government incumbency and regime type, shows the extent to which subnational economic interests have mattered in policymaking. The study finds that, despite Chile's small size and unitary form of government, subnational differences have played an important role in defining the nature and shape of the country's foreign policymaking, particularly during democratic periods and on issues where subnational economic differences were larger. Thus, if the explanation applies to Chile, which could be considered a "toughest test case", it may applicable in several other contexts (George and Bennett 2005, I2I) ${ }^{4}$.

\section{The Role of Subnational Politics in Commercial Policy in Latin America}

To explain variation in Chile's trade and foreign investment policy towards the United States I apply - and refine - the theoretical framework developed by Trubowitz (I998). His explanation of change in the definition of US national interest highlights the importance of regional economic differences in the formulation of national foreign policy. In a nutshell, the

\footnotetext{
4 However, electoral districts are territorially based so congresspersons respond to geographic constituencies (at least during democratic times). The lower house's relative malapportionment in favor of less populous, rural districts (Snyder and Samuels 2004) further accentuates regional competition. Additionally, successive governments since the I990s have also adopted political descentralization as a national policy, so subnational differences may also become more marked over time (Morgan 20I8).
} 
argument is that subnational economic specialization leads to divergent foreign policy preferences, which may cause conflicts over decisions made at the national level (Trubowitz I998, I4-I5).

Regional economic differences may translate, therefore, into different and sometimes conflicting regional foreign policy preferences. There are three main causes of region-specific foreign policy attitudes (Trubowitz I998, I5-I8). The first one is export dependence - the more a region depends on exports, the more likely it is that it will prefer free trade. Second, public foreign policy expenditures, especially in defense, have redistributive effects: the more a region can gain from these expenditures (for example in defense contracts and new facilities) the more it will support policies increasing them, while regions that only bear the costs (increased taxation, less social spending) will be less likely to promote them. Finally, structural economic differences and regional interrelationships may produce conflicts between regions when one region's benefit is the other's loss (Trubowitz I998, I5-I8).

At first sight, the Chilean case does not easily lend itself to an explanatory framework that emphasizes regional differences. While there is evidence that subnational interests affect trade policy in countries like Brazil, Argentina, and Mexico (Pezzola 2006; 20I3; 20I7), Chile differs substantially from these countries - and the USA - in one crucial dimension: size. With a population of about 7 million in I960 and I7 million in 20I0, and a land area just I0\% larger than Texas, Chile - and its economy - may seem too small to apply a framework that highlights subnational differences and competition. Another key difference is the system of government: while federalism "heightens the role of territoriality in structuring national politics" (Trubowitz I998, I9), Chile has a unitary system of government.

As in other resource-rich countries, however, the Chilean economy's main sectors are unevenly distributed in its territory. The Production Development Corporation (Corporación de Fomento de la Producción de Chile, CORFO), a Chilean governmental organization tasked with promoting economic growth, divided the country into economic zones for the first time in I950 (CORFO I965). Each one of these economic zones encompass two or more of the official first-level administrative divisions (regiones). The CORFO economic zones are traditionally labeled Norte Grande (Greater North), Norte Chico (Lesser North), Zona Central (Central Chile), Zona Sur (Southern Zone), and Zona Austral (Far South) (Collier \& Sater 2004, xix-xxi) ${ }^{5}$. Mining is primarily found in the northern regions of the country: copper, the country's main export, is produced along with other minerals in Norte Grande and to a

5 For a map of Chile's first-level administrative divisions and CORFO economic zones, see (CELADE n.d.). 
lesser extent in Norte Chico ${ }^{6}$. Agriculture is primarily found in Central Chile (the country's heartland where the overwhelming majority of the population lives) and in Southern and Austral Zones, where forestry and cattle farming are important. The manufacturing sector is concentrated in the cities of Valparaíso, Santiago, Concepción and their surroundings in the Zona Central.

This characterization is a rough portrayal of the last five decades of Chilean history. Even today, most mining operations occur in the Norte Grande and Norte Chico, manufacturing is still concentrated in the urban areas of the Zona Central, and most agricultural and forestry industries are located in the Zona Central and the southern zones. However, the country has experienced a horizontal export diversification 7 since the I980s (Ffrench-Davis 2002, I54, Agosin I999, 82-84), with more geographically-based sectors of the economy participating in exports (Herzer and Nowak-Lehnmann D. 2006, I828). Thus, although the regions have not changed their productive structures ${ }^{8}$, most have become more export-oriented. Figure I shows the fluctuating contributions to exports of each economic sector since I960 in Chile. For example, more than $80 \%$ of exports in the I960s corresponded to mining while industry contributed less than I0\%; in 20I0, mining exports still amounted to about $60 \%$ whereas industrial exports had increased to almost 30\%. Changes in each sector's contribution to exports may be associated with changing and sometimes diverging regional policy preferences.

Hypothesis I. Periods when Chilean regional economies diverge more on their export dependence experience more conflicts over trade and investment policy

6 The only major copper deposit not found in the northern regions is El Teniente, located in Central Chile. Deposits of sodium nitrate, which preceded copper as the country's main export, are also found in the Greater North (Dunning 2008, 216).

7 Horizontal diversification refers to the diversification of exports into new productive sectors. 8 Vertical (this is, value-added) export diversification has only occurred in a few industries (Herzer and Nowak-Lehnmann D. 2006, I828). 
Figure 1. Percentage of total exports of three sectors of the Chilean economy, 1960-2011. Source: author's elaboration based on BDE (2016)

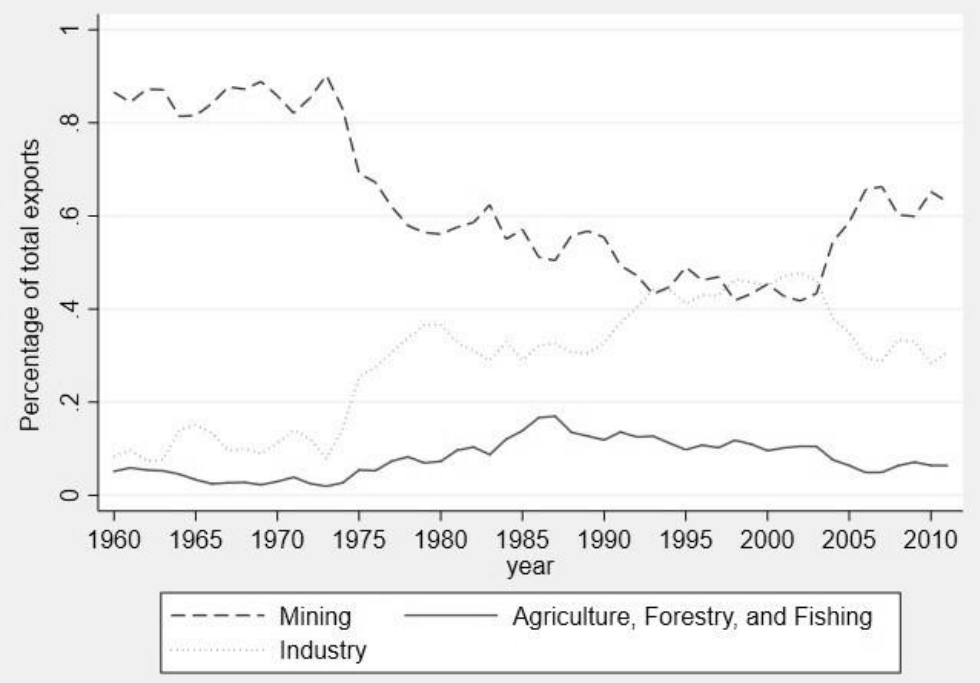

A regional approach may, therefore, find fertile soil in the Chilean case but it cannot be applied automatically, as presented by Trubowitz. The author's theory, based on the US experience, has to be refined with respect to the role of political institutions to have explanatory power in the case of a Latin American country like Chile. Regime type is virtually a constant in the US and therefore does not explain variance in policymaking. Like in the rest of Latin America, that is not the case in Chile. Indeed, regime change is one of the most important factors in Chilean and Latin American political history in the past half century.

Hypothesis 2. Representative and democratic institutions can accommodate regional conflict but in an authoritarian regime a more exclusive, smaller, and homogenous group holds power. Although these groups are, in practice, tied to specific interests (the military, industrialists, landowners) they also have high stakes as the sole rulers in the wellbeing of national economy, and are less prone to unnecessary logrolling (Snyder I99I, 52-54). Policymaking in authoritarian regimes is based less on representation (including geographic representation) and is more likely to lead to sweeping and sometimes unpopular decisions. As Haggard I990 (262) argues, "[s] ince authoritarian political arrangements give political elites autonomy from distributionist pressures, they increase the government's ability to extract 
resources, provide public goods, and impose the short-term costs associated with economic adjustment."

Democratic institutions allow regional differences to have a larger effect in Chilean trade and investment policy than authoritarianism

\section{Agrarian Reform and Nationalization of Copper: Conflict and Consensus Along Regional Lines}

During the governments of Christian Democrat Eduardo Frei Montalva (I964-I970) and Socialist Salvador Allende (I970-I973), Chile experienced a period of heightened social and political polarization. Conflict over foreign investment with the USA revolved primarily around the issue of the ownership of Chile's vast copper reserves. These resources had been in the hands of US companies - most notably Anaconda and Kennecott - since the beginning of the twentieth century. According to Petras and Morley (I975, 8-9),

US direct private investment in Chile in I970 stood at \$I.I billion, out of a total estimated foreign investment of $\$ 1.672$ billion. Despite the diversification of investment in the I960s, away from extractive industries and related service industries and toward manufacturing, trade, and banking, the bulk of private investment in Chile remained in the mining and smelting sector (over 50 percent).

This situation, together with dissatisfaction over the companies' performance, motivated Frei Montalva to promote "Chileanization" (state ownership of $51 \%$ ) in 1966 , and then moved Allende to nationalize (acquire full state ownership though expropriation) of the copper industry in I97I.

Does it make sense to talk about policy conflicts along regional lines in this period? Negotiations took place between companies and the Executive but Congress had to pass constitutional amendments and laws allowing the legal transfer of property from the companies to the state. Different groups advanced "their own conceptions of the national interest through manipulation of copper policy" (Moran I974, I69).

Economic zones played a major role in this process. The arid, mostly urban, and mining Norte Grande and Norte Chico regions were commonly represented in Congress by Centre and leftist parties: Christian Democrats, Radicals, Socialists and Communists (J. Petras and Zeitlin I967)9. Electoral

9 Copper workers were first and foremost allied with the Communist Party, whose ties with 
divisions in Central Chile, the Southern Zone and the Far South were along urban/rural lines: urban and industrial centers tended to elect more Centre and leftist representatives while rural and agricultural sectors were usually represented by Right-wing politicians from the Liberal and Conservative parties.

These zones had markedly different economic structures. The economy of the northern provinces was export-oriented. Taxation of mining companies was crucial for the state: between the Second World War and I973, ten to 40 percent of government expenditures came from copper tax revenues (Moran I974, 6). The industrial sector, located primarily in the populous cities of the Zona Central, was inward-oriented, following the ISI model. The agricultural sector was controlled by a handful of landowners and groups through enormous haciendas. This sector was so inefficient that food had to be imported to meet domestic demands (Correa et al. 200I, 222).

The main conflict, however, was not between the nationalist Left and Centre on one side and a laissez-faire Right allied with the multinational conglomerates, on the other. In reality, all groups wanted the Chilean state to obtain more revenues from copper exports in order to promote the industrial growth of the country. Indeed, political parties "held divergent views on free enterprise, labor unions, and relative distribution of income in Chilean society, but they joined in wanting to protect and expand the country's industrial base" (Moran 1974, I87). The crux of the matter was how to use copper revenues to promote economic development. Communists and Socialists had been pleading the case for nationalization for decades; the Right, on the other hand, had preferred to reach agreements with the companies to increase production. Above all, Right-wing politicians did not want a constitutional reform that would allow the state to expropriate private property from the US mining companies, because such reform could allow for expropriations among their own constituents.

This reluctance by the Right eventually disappeared due to the Alliance for Progress and the measures taken during the presidency of Frei Montalva. Frei had promised to enact sweeping economic reforms, including the Chileanization of copper, and a new Agrarian Reform. The Alliance for Progress was essential for the latter, as funds from the Alliance were used to carry out the reform. Formulated in 1961 by the Kennedy administration, the program aimed to address the grievances that had led to the Cuban revolution by providing economic assistance. Shortly after its announcement,

miners' unions dated back to the nitrate boom. The coal mining areas of Central and Southern Chile were also a bastion of the Communist Party. Centrist Christian Democrats in the north had the support of less-organized sectors and the poor in urban areas (Vergara 20I2, 66-67). 
Conservative senator Francisco Bulnes Sanfuentes reacted against the proposed reforms brought by the Alliance,

There is no need for social change in Chile, since the country has had many social laws on the books for over 50 years. It would be better if the United States quit stirring up our economic and social problems. What the country does need is huge new investments in copper production [...] Therefore, if the companies cannot be made to launch a huge new program and let the proceeds flow to develop Chile as the Alliance envisions, the government should nationalize them! (Bulnes Sanfuentes I96r)

For the Christian Democrats in power, the reform's goals were twofold: redistributing land to increase productivity to reduce pressures on the balance of payments, and breaking the traditional clientelistic peasant-landowner relationship that the Right enjoyed in the countryside (Correa et al. 200I, 248, Kay 2002, 468).

Congressmen from rural districts of the Central and Southern regions of the country were opposed to such reform. They considered foreign copper companies to be more responsible than domestic landowners for the country's underdevelopment (Moran I974, 200). The Right's decision was therefore to give its conditional support to the nationalization of the copper industry, tying the reform of Article Ten of the 1925 Constitution (containing the right of property) to reducing the extent of the Agrarian Reform (Fermandois, Bustos, and Schneuer 2009, I06; Moran 1974, 206) - a textbook example of logrolling. Senator and National Party President Sergio Onofre Jarpa (a former member of the Agrarian Labor Party), for example, stated, "Naturally, we do not promote unconditional support for [the US] government, which also acts according to its own interests, and that is not exempt from making errors or mistakes. We promote an independent, practical and realist attitude to serve Chile's goals" (El Diario Ilustrado I969). Opponents of the reform cut across party lines, however, and also included politicians from other parties with rural constituencies. As Moran (I974, 205) recounts,

The Conservative Party, which had the largest constituency of landowners, was most explicit in its strategy of holding the destiny of the copper companies in suspension until modification could be negotiated in the Agrarian Reform. But the concerns of the Conservatives were also preoccupying members of the Liberal, Radical, and even Christian Democratic Parties, many of whose members were themselves large landlords. In October 1965, for example, El Diario Austral de Temuco (in the rich agricultural south) reported that the entire Christian Democratic 
leadership of that important city had resigned over disputes with the party headquarters in Santiago about the Agrarian Reform.

Despite the Right's opposition (and due to its poor electoral results I965, which caused the Conservative and Liberal Parties to fuse into the National Party), the Frei government gained enough support from urban and industrial sectors (from the Centre and Right but not from the Left ${ }^{\mathrm{I}}$ ) to pass the Agrarian Reform, change Article Ten of the Constitution, and approve Chileanization.

When the government policy went from Chileanization to Nacionalización Pactada ("Agreed Nationalization") the Right had therefore nothing to lose (as the Agrarian Reform had already been passed) and no reason to support the US companies. In the words of senator Jarpa, "The United States told us to have an Agrarian Reform with 30-year terms of payment. I think we ought to apply the same system to [Anaconda and Kennecott], and I am sure that the United States won't object, in any case we won't support Anaconda...if this plan [to nationalize] is serious, we will support it" (quoted in Moran I974, 2I2).

It comes as no surprise then that when President Allende pushed for complete and immediate nationalization with practically no compensation he received unanimous support from Congress. As Allende (I988, 65) observes, "[t]his was a clear reflection of the country's feelings regarding the copper sector, especially given the ongoing political confrontation between the government and the opposition." The Right supported nationalization as long as it did not affect other companies - because it was still resentful towards the USA for its support of the Agrarian Reform (S. Collier and Sater 2004, 334). This resentment stemmed from the fact that the Agrarian Reform not only redistributed its constituents' land but also destroyed Conservatives' foothold in the rural electorate of the Central and Southern Zones. The Left and the Christian Democrats took advantage of the reform to unionize and mobilize thousands of peasants electorally (J. Petras I973, 38-39, Correa et al. 200I, 49).

\section{Denationalizing Copper and Undoing the Agrarian Reform: Major Changes and Continuities with a Stifled Regional Debate}

The September II, I973 military coup against Allende brought an end

Io Communists and Socialists had opposed Frei's Chileanization because they deemed it insufficient (S. Collier and Sater 2004, 3I7, Fermandois, Bustos and Schneuer 2009, I03). 
to democratic politics in Chile for seventeen years. Did the overthrow also suspend trade and foreign investment policymaking along subnational lines? The military regime undid many of the reforms carried out by the previous two administrations, and invited several Right-wing politicians to participate in the government. There is no evidence, however, that the dictatorship's policies towards the United States was the outcome of subnational conflicts. The opening of the Chilean economy to the international market and largescale privatizations were the product of the debate among groups within the military government and their advisors (Allende I988) rather than broader, geographically-based factions.

With regards to mining, the military regime's most important actions were reaching out to foreign investment again but at the same time preserving CODELCO (the state-owned company). Indeed, the regime's first international action was announcing that Anaconda, Kennecott, and other US companies would be compensated for the expropriation of their Chilean assets (Fermandois, Bustos \& Schneuer, 2009, I29, Muñoz \& Portales, I99I, $50)$. The government also reopened the mining sector to foreign investment, changed the legislation to equalize their tax burdens to domestic companies, and took other measures to make mining investments more attractive (Fermandois, Bustos \& Schneuer 2009, I40). As a result, "in the I974-I983 period out of all the authorized foreign investment projects, $79 \%$, this is, 5,729 million dollars were mining projects, being most of them for copper" (Fermandois, Bustos \& Schneuer 2009, I36).

Despite the opening of foreign investment and trade, the military government decided to keep CODELCO in public hands. During a discussion between businessman and Minister of Economy Fernando Léniz and the Government Junta about the possible privatization of CODELCO, Admiral José Toribio Medina responded that they would not undo what Congress had unanimously approved (Fermandois, Bustos \& Schneuer 2009, I29-I30).

By contrast, the effect of regime on industry in Central Chile and on agriculture, forestry, and fishing in the Centre and South meant substantial changes on those regions' economies. Figure 2 shows how these two regionally concentrated sectors increased their exports since the I980s. Agricultural, forestry and fishing exports in I960 were almost negligible but fifty years later amounted to 5 billion dollars. Industrial exports were similarly small in I960 but started to increase in the mid-I970s and increased to more than 22 billion dollars in 20 Io. 
Figure 2. Exports of two economic sectors of Chile, 1960-2010. Source: author's elaboration based on BDE (2016)

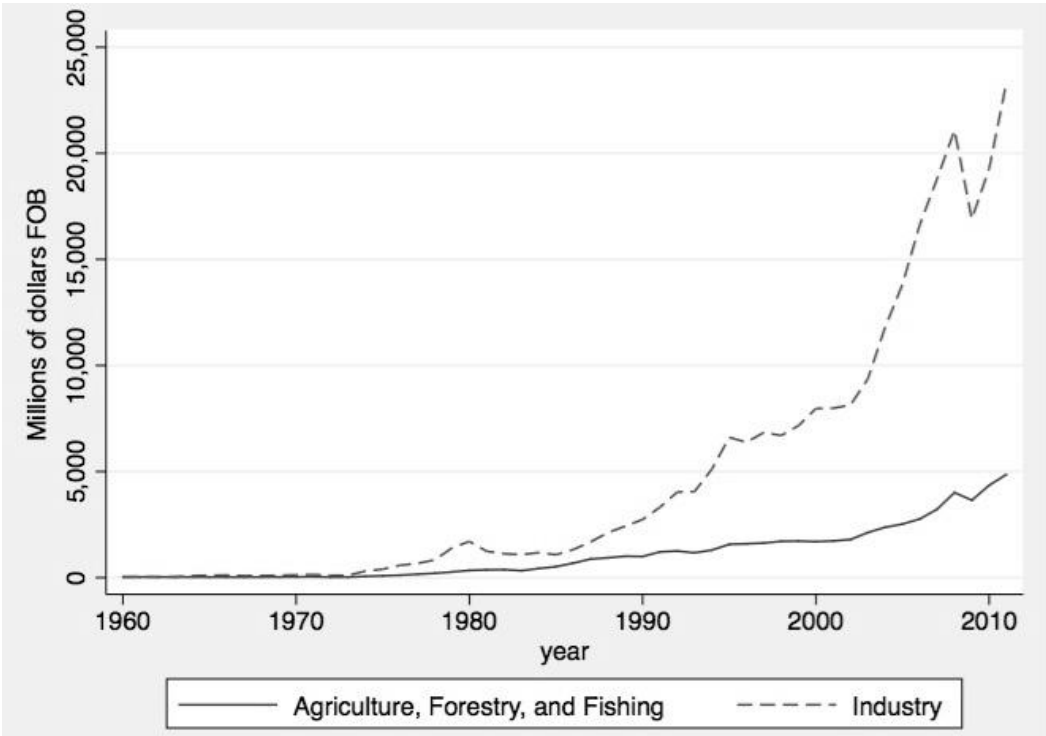

First, the military government unraveled the Agrarian Reform carried out by the previous two administrations - but it did not revert the situation back to the original latifundia system. About a third of the expropriated lands were returned to their original owners while the majority were sold or assigned to individual peasants (thus ending the communal properties sponsored by the previous governments). More importantly, the change promoted a new export-oriented system. Peasants who could afford to run their farms became seasonal workers or joined the ranks of the urban poor, while many landowners who recovered their properties ultimately decided to sell them because they could not adjust to the increasingly competitive and outward-oriented agricultural sector (Kay 2002, 472).

Manufacturing was also hard-hit and transformed. The government unilaterally reduced import tariffs from about 70\% to I0\% in ten years, which had catastrophic effects on the local manufacturing industry (S. Collier and Sater 2004, 366). Trade openness also made the Chilean economy susceptible to the international crises of the late I970s and early I980s. The social cost was unquestionable - the level of workers' wages in 1970 was only recovered in I990, and the percentage of people under the poverty line rose from $28 \%$ in 1970 to $44 \%$ in I980 (Correa et al. 200I, 294). From this general decline more competitive enterprises emerged, however: 
The neoliberal renewal of Chilean capitalism and the privatization process of state-owned companies, the generation of new markets and the opening to the international economy, all had a significant impact on the dismantling and rearticulation of economic elites. With few exceptions the main investors and holding groups in 20I0 differ from those forty years prior, [and] the way of doing business differs substantially of the way they operated a few decades ago (Undurraga 2014, 2).

These changes caused an economic crisis in the industrial regions of the country. While Santiago was able to recover (mostly through the growth of the service economy), other major industrial cities like Valparaíso and Arica never fully regained their economic status (Szary I997).

Subnational conflicts were not voiced while the regime was radically changing the economic landscape of the country. However, this does not mean that the military was governing on behalf of a single economic sector or that there was complete consensus among the government and its associates, particularly the group of neoliberal economists known as the Chicago boys (Montecinos 2009, Markoff and Montecinos I993, Puryear 1994). These economists had a great deal of influence but their reach could not get to areas where the military considered it was defending the national interest. The military regime did not privatize CODELCO, while reintegration of private and foreign capital in the mining northern regions accentuated their exportoriented nature, a strategy that had both neoliberal and nationalist elements (Wilhelmy and Durán 2003, Allende I988).

\section{The USA-Chile FTA and the Royalty Tax: Deepening Liberalization and Consensus}

The return to democracy with the Centre-Left Concertación party coalition (I990-2010) could have, in theory, allowed for regional differences to influence policymaking. However, in terms of commercial policy towards the USA, this period prolonged and deepened the policies implemented during the dictatorship. This continuation resulted in increased trade with the US and the rest of the world: as Morandé $(2003,252)$ recounts, "in a period of only ten years (I990-1999), Chile doubled its overall foreign trade (from \$I billion to \$30 billion), with 90 percent of total trade being almost evenly distributed between the United States, Latin America, the European Union, and the Asian member-states of APEC." Two milestones may lead to think that subnational level differences did not matter in policymaking anymore. The first one is the rapprochement with the USA, which culminated in the 
ratification in the Chilean Congress in 2003 of the FTA. The second one is the relative lack of discussion of the private ownership of copper, compared to the I964-I970 period, until the approval of a law to impose a tax (called "Royalty" by the press in Chile) on private mining activities in 2005 .

Did subnational politics play any role in the 2004 FTA with the USA? The treaty was approved by 87 deputies $(84.5 \%)$, and 35 senators $(77.3 \%)$. At first glance, it seems like the neoliberal consensus did not allow for any regional distinctions. However, this apparent high degree of consensus masked "a vigorous controversy centred on its perceived implications for the country's traditional agricultural sector" (Leight 2008, 226), and was only possible after the transformation in the subnational economic structures the began in the Ig8os. These changes caused the country's diverse regions to converge towards export-oriented policy preferences.

Indeed, most of the deputies and senators who voted against the FTA or abstained represented low-income and inward-oriented districts from the Central and Southern Zones. As Table I shows, the members of Congress who voted against of abstained from ratifying the FTA belonged to both government and opposition parties but virtually all of them represented districts from the traditionally agricultural regions of Central and Southern Chile, and their opposition broke party discipline (Agüero 2005, 57).

Table 1. Members of Congress voting against or abstaining from ratifying the FTA with the United States in 2003. Source: author's elaboration based on BCN (2003: 273-274, 681-682, 2018)

\begin{tabular}{|l|l|l|l|l|}
\hline \multicolumn{1}{|c|}{ Member } & \multicolumn{1}{|c|}{ Action } & \multicolumn{1}{|c|}{ Chamber } & Party (Coalition) & \multicolumn{1}{c|}{$\begin{array}{c}\text { Congressional } \\
\text { District (Region) }\end{array}$} \\
\hline Sergio Aguiló & Against & Lower & $\begin{array}{l}\text { PS } \\
\text { (Concertación) }\end{array}$ & 37 (Maule) \\
\hline Germán Becker & Against & Lower & RN (Alianza) & 50 (Araucanía) \\
\hline $\begin{array}{l}\text { Roberto } \\
\text { Delmastro }\end{array}$ & Against & Lower & RN (Alianza) & 53 (Los Lagos) \\
\hline $\begin{array}{l}\text { José Antonio } \\
\text { Galilea }\end{array}$ & Against & Lower & RN (Alianza) & 49 (Araucanía) \\
\hline $\begin{array}{l}\text { René Manuel } \\
\text { García }\end{array}$ & Against & Lower & RN (Alianza) & 52 (Araucanía) \\
\hline $\begin{array}{l}\text { Rosauro } \\
\text { Martínez }\end{array}$ & Against & Lower & RN (Alianza) & 4I (Biobío) \\
\hline $\begin{array}{l}\text { Nicolás } \\
\text { Monckeberg }\end{array}$ & Against & Lower & RN (Alianza) & 42 (Biobío) \\
\hline
\end{tabular}




\begin{tabular}{|c|c|c|c|c|}
\hline Osvaldo Palma & Against & Lower & $\begin{array}{l}\text { PPD } \\
\text { (Concertación) }\end{array}$ & 39 (Maule) \\
\hline Eduardo Díaz & Abstention & Lower & UDI (Alianza) & 5I (Araucanía) \\
\hline $\begin{array}{l}\text { Maximiano } \\
\text { Errázuriz }\end{array}$ & Abstention & Lower & RN (Alianza) & $\begin{array}{l}29 \\
\text { (Metropolitana) }\end{array}$ \\
\hline $\begin{array}{l}\text { Javier } \\
\text { Hernández }\end{array}$ & Abstention & Lower & UDI (Alianza) & 55 (Los Lagos) \\
\hline Pablo Prieto & Abstention & Lower & $\begin{array}{l}\text { Independent } \\
\text { (Alianza) }\end{array}$ & 37 (Maule) \\
\hline Carlos Recondo & Abstention & Lower & UDI (Alianza) & 56 (Los Lagos) \\
\hline $\begin{array}{l}\text { Alejandra } \\
\text { Sepúlveda }\end{array}$ & Abstention & Lower & $\begin{array}{l}\text { DC } \\
\text { (Concertación) }\end{array}$ & 34 (O’Higgins) \\
\hline Ignacio Urrutia & Abstention & Lower & UDI (Alianza) & 40 (Maule) \\
\hline $\begin{array}{l}\text { Gastón von } \\
\text { Mühlenbrock }\end{array}$ & Abstention & Lower & $\begin{array}{l}\text { Independent } \\
\text { (Alianza) }\end{array}$ & 54 (Los Lagos) \\
\hline Nelson Ávila & Against & Upper & $\begin{array}{l}\text { Chile V } \\
\text { (formerly } \\
\text { Concertación) }\end{array}$ & 6 (Valparaíso) \\
\hline José García & Against & Upper & RN (Alianza) & I5 (Araucanía) \\
\hline Jorge Lavandero & Against & Upper & $\begin{array}{l}\text { DC } \\
\text { (Concertación) }\end{array}$ & I5 (Araucanía) \\
\hline Mario Ríos & Against & Upper & RN (Alianza) & I3 (Biobío) \\
\hline $\begin{array}{l}\text { Mariano Ruiz- } \\
\text { Ezquide }\end{array}$ & Against & Upper & $\begin{array}{l}\text { DC } \\
\text { (Concertación) }\end{array}$ & I3 (Biobío) \\
\hline Marco Cariola & Abstention & Upper & UDI (Alianza) & I6 (Los Lagos) \\
\hline Alberto Espina & Abstention & Upper & UDI (Alianza) & I4 (Araucanía) \\
\hline Hernán Larraín & Abstention & Upper & UDI (Alianza) & II (Maule) \\
\hline Rafael Moreno & Abstention & Upper & $\begin{array}{l}\text { DC } \\
\text { (Concertación) }\end{array}$ & 9 (O’Higgins) \\
\hline Rodolfo Stange & Abstention & Upper & UDI (Alianza) & I7 (Los Lagos) \\
\hline
\end{tabular}

Most of the reasons for not supporting the FTA evidence a subnational economic rationale. During the floor discussion of the FTA in the Chamber of Deputies, Alejandra Sepúlveda (DC), who abstained, declared,

Today we see this Free Trade Agreement as an instrument that ensures economic stability to small producers, and when I see a farmer from [...] some of the communes that I represent in this Chamber I must recognize 
that these farmers will have to go from a traditional agriculture, noncompetitive, that is not open, to the markets [...] How much do these farmers need to carry out an exporting process and insert themselves somehow into the international markets? (BCN 2003, 239).

Virtually all the Deputies and senators from Araucanía the region in the Southern Zone decided not to support the FTA. This region, the country's least developed, was ill-prepared to face the arrival to the Chilean market of US wheat, beef and other foodstuffs. Senator Espina (UDI), who abstained, called the potential elimination of wheat price bands "the first brutal negative impact" of the FTA on the region (BCN 2003, 655). Deputy José Antonio Galilea (RN) clearly expressed the negative effects of the FTA on his district,

Before this dilemma I have taken the decision to vote against, because I feel it is my moral duty to privilege the region and, above all, the district that elected me into this Chamber. Ours is the poorest region - 30 percent is under the poverty line - and it is the one that exports the least -0.2 percent of the total. And I am even more resolute to make this decision when the government, during the whole discussion of the project, has not given any signal or proof of willingness to want to produce the deep changes the regions need, because they are the ones that seem to lag behind in the face of the challenges being imposed. What do we have? Territories, economic activities and business owners of different sizes incorporated to the exporting process, who take advantage of the treaties, make profits and generate development. But we also have in vast areas of the regions of Maule, Biobío, Araucanía, and Los Lagos important activities that sustain those economies, and thousands of small- and medium-sized business owners and peasants who are not incorporated into the exportsbased model, and who probably make less profits, but are essential for the survival [of the regions] and their surroundings (BCN 2003, I00).

Their views represented a minority but clearly show a division on the issue of the FTA along subnational lines, and across party and ideological divisions. In the words of Baeza and López $(2015,40)$, "the main source of rejection of the FTA with the USA was not ideological barriers or rejection of globalization or capitalism but the protection of subsidies, price bands, and other prerogatives enjoyed by the political clientele in the electoral districts of all political parties." The non-export-dependent areas of rural Central and Southern Chile were getting the short end of the stick in the FTA with the USA, and their members of Congress unsuccessfully opposed it. These representatives did, however, save face by getting a phasing-out process for 
sugar and wheat price bands for their constituents ${ }^{\text {II }}$. The process started in 2008, with price bands disappearing in 2014 (Leight 2008, 23I; Baeza and López 2015, 49).

The market-friendly consensus also marked the discussion of the issue of private ownership of copper - a critical matter in the political debates of the Ig6os and I970s. As Fermandois, Bustos, and Schneuer (2009, I27), explain,

With the return to democracy there should have been a renaissance of the 'question of copper' and of the attempts to 'control' the resources that come from the red metal...It was not the case, however, at least not until 2004. The economic transformations of the military government did not end up being mere impositions of the rulers of the time.

After the return to democracy, production by foreign companies greatly outpaced that of CODELCO, as Figure 3 shows. In the I996-2010 period, for example, private companies had gone from producing less than 2 million metric tons of copper to more than 3.5 million. State-owned production lagged behind, increasing by less than 500,000 metric tons. The surge in the price of copper (it nearly tripled between I996 and 2006), caused Concertación politicians to question the favorable fiscal conditions under which these largescale companies operated. An initial attempt to increase their tax burden was thwarted in 2004 by the Center-Right opposition, with some representatives from mining regions expressing fear that a change in the terms would scare away foreign investment (Napoli and Navia 2012, I63). ${ }^{\mathrm{I2}}$ However, a modified, scaled-down version was finally approved in 2005 .

II Other measures like compensation subsidies for the affected farmers were unsuccessful (El Mercurio 2003). Southern members of Congress had managed to get compensation funds for the agricultural sector in the past, as part the deal for Chile's accession to the Mercosur common market in I996 (Porras 2003).

I2 Carlos Vilches (RN), a Norte Chico district deputy, was one of two Center-Right politicians who supported the 2004 bill. He argued that the tax hike would "restore the lost dignity and historic imbalance that the mining regions had vis-à-vis Santiago" (El Mercurio 2004). 
Figure 3. Production of fine copper by state-owned and private companies, 1996-2006. Source: author's elaboration based on Fermandois, Bustos, and Schneuer (2009)

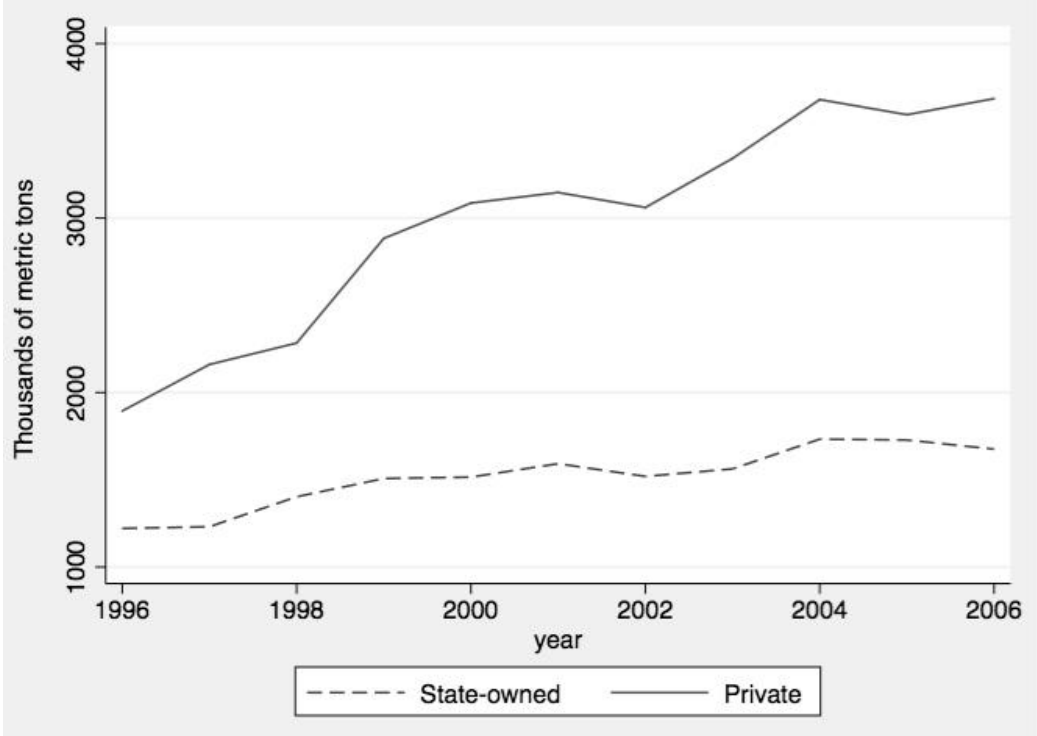

Did regional interests influence the decision to pass the 2005 Royalty? During its first stage, the bill received 86 affirmative votes, fourteen negative ones and eight abstentions in the Lower House, and 28 affirmative votes, 5 negative ones, and 6 abstentions in the Senate (BCN 2005, I09, 2I2). Unlike the approval of the US-Chile FTA, the 2005 Royalty was approved by the Center-Left en bloc in the Chamber of Deputies. Fifteen out of twenty-nine opposition deputies also approved the bill (the rest voted against). Only one Centre-Left senator voted against (because he considered it did not go far enough); from the Center-Right senators, the bill received 9 affirmative votes, four nays, and six abstentions. Thus, the government legislators supported the bill, while the opposition became divided.

The success of the 2005 bill, vis-à-vis the previous year's attempt, can be partly explained through regional differences. When the bill was being discussed on the floor, legislators from both the government and the opposition argued that the revenues had to be invested in the mining regions. For example, Senator Cantero (RN) from the Norte Grande Region of Antofagasta, who opposed the 2004 bill but supported the 2005 version, expressed the following, 
[T] he areas where nonrenewable natural resources are extracted suffer from depredation and impoverishment as they are exploited. Therefore, it is absolutely convenient to look for sustainability in development through the generation of new moneys from particular taxes. What is important is that, if the system is oriented towards nonrenewable natural resources, it is absolutely reasonable to have a percentage of the moneys coming from the tax to go and benefit the sustainable development of mining zones, and not others, without leaving the central government as the sole arbiter deciding the destination of these funds. As a result, I deem that this future law must destine specific and clearly defined resources towards the appropriate mining regions (BCN 2005, 204).

This caused the President to modify the bill by introducing an Innovation Fund for Competitiveness (Fondo de Innovación para la Competitividad, FIC), which guaranteed all regions a certain amount of the revenues coming from the Royalty, with mining regions getting extra resources. The introduction of the FIC caused some legislators to commit their support for the 2005 version of the Royalty (Napoli and Navia 2012, I68-69).

There is also evidence that some opposition legislators opposed the Royalty based on subnational interests. Indeed, many of the legislators from the North had hoped that a larger part of the revenues would return to the districts where the mines are exploited. At least in two cases, this caused them vote against the new tax. Mario Bertolino (RN), a deputy from a Norte Chico region who voted against the bill, pointed to an interregional conflict in the floor discussion,

What will happen with the mining regions, with the mining communes, which are the ones impoverished by the extraction of minerals, which is a nonrenewable resource? It has been said they will be assigned I5 percent of the resources. This worries me because non-mining communes and regions have the capacity, the specialization, and the appropriate professionals to gain access to those innovation projects [from the FIC]. Therefore, we would once again be extracting resources from the mining zones to transfer them to the national treasury, invest them in Greater Santiago to get more subways and better roads there. And the regions will keep on waiting (BCN 2005, I47).

Senator Evelyn Matthei (UDI), who also represented a Norte Chico district, abstained because she considered her region to be unfairly treated in the negotiations, 
I will also formulate an indication so that resources can reach municipalities located where there are mines that pay the Royalty. Because when the minerals run out [...] unemployment rises in the region; a gap is left in the zone or the commune where the deposit is located. Hence, the money coming from the Royalty must also stay there. I do not see why other regions, which do not experience the problems of mining, have to benefit from it (BCN 2005, 320).

\section{Conclusion}

Chile is a small country with a relatively small economy, which has always been subject to external economic and political pressures. Domestic factors like class conflict, party politics, and regime change have also been important variables in its trade and foreign investment policy towards the USA. This article, however, demonstrates that geographically-based economic interests should not be ignored when it comes to defining policymaking and the discourse and behavior of individual political actors, particularly in democratic periods.

Indeed, this work contributes to the literature on the factors that cause legislators to pay more attention to their constituencies. While some works argue that legislators become more constituency-oriented for institutional (Alemán, Ramírez, and Slapin 20I7, Crisp and Desposato 2004), electoral (André, Depauw, and Martin 2015, Lazarus 2009; Fukumoto and Matsuo 2015), intraparty (Dockendorff 2019, Fenno I978, Norris I997), biographical (Dockendorff 20I9, Russo 20II) and demographic (Dockendorff 20I9, Atlas, Hendershott, and Zupan I997, Gamboa and Toro 20I8) reasons, this analysis suggests that they also privilege their constituencies when there are marked economic differences between districts. These high-stakes differences may cause individuals and interest groups to pay more attention to their representatives' actions in Congress (Stein and Bickers I994).

The I964-I973 period witnessed conflict between different regionallybased factions. The complex relationship between Agrarian Reform and the Chileanization and Nationalization of copper demonstrate how conflict about economic and development policies in general and particularly foreign investment policies can follow regional lines, especially when subnational economic structures differ. In the words of Trubowitz (I998, I7), "when one region's gain is another's loss, conflict can arise." The landowners of the backwards rural areas in the Central and Southern Zones were unwilling to bend the rules of private ownership to promote the national goal of industrialization through the use of copper revenues. However, once the 
Right was defeated electorally, and when it saw itself betrayed by the USA, its unwillingness to cooperate with the urban and industrial Centre and Left disappeared. As one expert quoted by Dunning $(2008,228)$ puts it, "no one on the Right was not going to offer up the [copper companies] to the gods". Although party, ideological, and subnational interests sometimes overlapped, events unfolded along primarily subnational economic lines, so explanations that only emphasize ideological or party competition are insufficient in this case, which lends support to the first hypothesis.

The Pinochet years, in contrast, saw the stifling of conflict along regional lines. Rather, there was an initial competition within the regime in which neoliberal policymakers ultimately prevailed - even though the military maintained CODELCO, the nationalized copper company. In those times of crisis most of the changes in the Chilean economy and its trade and foreign investment relationships with the US can be explained almost completely through unrestrained economic ideology (Gourevitch 1986, 62). In this case, policies purposefully adjusted the economic structure of the country's regions by opening them up to the international markets and increasing their competitiveness - although at a very high social cost. The subnational approach to foreign policy, therefore, is less useful without the institutional framework provided by democracy that supports geographically-based and broad social conflicts, which lends support to the second hypothesis.

The return to democracy could have also portended the return to differences in subnational policy preferences. In terms of the outward orientation of regional economies, however, there were fewer subnational differences, which decreased conflicts among their representatives in Congress. Indeed, the liberalizing and export-oriented policies initiated during the dictatorship survived the transition: once in power, Concertación advanced the model it had inherited from the dictatorship instead of trying to replace it with statist or autarkic policies ${ }^{13}$. Nevertheless, what little dissent surfaced in the case of the Chile-USA FTA did take a subnational form. As Trubowitz (I998, I5) argues, "[r]egions that are heavily dependent on the home market or less well placed in global competition are more likely to support active government intervention to shelter or protect their markets from foreign competitors." These districts, located primarily in rural Southern Chile were few, small and declining, and were thus unable to stop the ratification of the FTA. However, as Borges 2017 (I4-I5) explains,

I3 These foreign policy stances also continued after 20I0 under President Sebastián Piñera (Oyarzún 2013). 
Chilean legislators, including those from the ruling coalition, acted not only as a check on the executive's actions but also as a counterweight. They generated their own proposals for addressing the FTA's most controversial effects. In doing so, they challenged their own parties and defended the interests of those who voted them into office.

The evidence suggests, therefore, that the relative success of government bills related to international agreements in Chile since I990 is not only caused by Congress deferring to the Executive on foreign policy (Alemán and Navia 2009, 405-6), but may also be a function of a high degree of consensus in the Legislative branch, which stems from the increasingly export-oriented nature of the Chilean regions.

By contrast, the case of the approval of the 2005 Royalty mining tax imposed on foreign investment provides mixed support for the first hypothesis. The promise of windfall tax revenues from copper exports did not convince members all members of Congress. While legislators from the government supported the bill, the opposition became divided. Some CenterRight parliamentarians from mining districts supported the tax because of it promised new resources for their regions (which proved critical for the success of the bill), while others opposed the Royalty due to the negative consequences of mining on their constituencies without being properly compensated. Hence, this second democratic period shows that the importance of subnational units in foreign policy is also a function of how their economic structures diverge or converge over time. Structural factors like hegemonic pressures, policy innovations, and commodity booms may always require a policy response from a small country like Chile, but the nature of that response can still be shaped by domestic and subnational considerations.

\section{REFERENCES}

Agosin, Manuel. I999. "Trade and Growth in Chile." Cepal Review, no. 68: 79-100.

Agüero, Felipe. 2005. "El Acuerdo de Libre Comercio Chile-Estados Unidos." Colombia Internacional 61: 50-62.

Álamos, Pilar. I999. "Algunas Fuentes Históricas de La Política Exterior de Chile." Estudios Internacionales 32 (I26): 3-39. https://doi. org/10.2307/41391622.

Alemán, Eduardo, and Patricio Navia. 2009. "Institutions and the Legislative Success of 'Strong' Presidents: An Analysis of Government Bills in 
Chile." The Journal of Legislative Studies I5 (4): 40I-I9. https://doi. org/I0.1080/1357233090330247I.

Alemán, Eduardo, Margarita M. Ramírez, and Jonathan B. Slapin. 2017. "Party Strategies, Constituency Links, and Legislative Speech: Party Strategies, Constituency Links, and Legislative Speech." Legislative Studies Quarterly 42 (4): 637-59. https://doi.org/IO.IIII/lsq.I2I74.

Allende, Juan Agustin. I988. "Historical Constraints to Privatization: The Case of the Nationalized Chilean Copper Industry." Studies In Comparative International Development 23 (I): 55-84. https://doi.org/IO.I007/ BF02686999.

André, Audrey, Sam Depauw, and Shane Martin. 2015. "Electoral Systems and Legislators' Constituency Effort: The Mediating Effect of Electoral Vulnerability." Comparative Political Studies 48 (4): 464-96. https:// doi.org/IO.II77/00I04I40I45455I2.

Atlas, Cary M., Robert J. Hendershott, and Marka. Zupan. I997. "Optimal Effort Allocation by U.S. Senators: The Role of Constituency Size.” Public Choice 92 (3): 22I-29. https://doi.org/Io.I023/A:I0I796000I456.

Baeza, Jaime, and Miguel Ángel López. 20I5. "El Congreso Nacional de Chile y El Proceso de Ratificación Del Tratado de Libre Comercio Con Los Estados Unidos de América." Estudios Internacionales 47 (I82): 37-55. https://doi.org/10.5354/0719-3769.2015.37883.

BCN. 2003. "Historia Del Decreto Supremo No 3I2." Biblioteca del Congreso Nacional de Chile. http://www.leychile.cl/Navegar?idNorma=219844.

BCN. 2005. "Historia de La Ley No 20.026." Biblioteca del Congreso Nacional de Chile. https://www.bcn.cl/historiadelaley/nc/historia-de-la-ley/5759/.

BCN. 20I8. "Miembros Del Congreso Nacional de Chile." Biblioteca Del Congreso Nacional de Chile. 20I8. https://www.bcn.cl/historiapolitica.

BDE. 20I6. "Base de Datos Estadísticos: Sector Externo: Información Histórica: Comercio Exterior: Exportaciones de Bienes." Base de Datos Estadísticos Banco Central de Chile. 20I6. https://siz.bcentral.cl/Siete/ secure/cuadros/arboles.aspx.

Borges, Fabian A. 20I7. "Debating Trade: The Legislative Politics of Free Trade Agreements in Latin America." Government and Opposition, October, I-29. https://doi.org/IO.IOI7/gov.20I7.28.

Bulnes Sanfuentes, Francisco. I96r. "Chile Frente a La Alianza Para El Progreso." El Diario Ilustrado, July 2, I96I.

CELADE. n.d. "Chile: Zonas Según Región." Centro Latinoamericano $y$ Caribeño de Demografía. Accessed January 25, 2018. https://www. 
cepal.org/celade/noticias/paginas/9/40459/CHLesqor.jpg.

Colacrai, Myriam, and María Elena Lorenzini. 2005. "La Política Exterior de Chile: ¿excepcionalidad o Continuidad? Una Lectura Combinada de 'Fuerzas Profundas' y Tendencias." CONfines 2: 45-63.

Collier, Ruth Berins, and David Collier. 2002. Shaping the Political Arena: Critical Junctures, the Labor Movement, and Regime Dynamics in Latin America. Notre Dame: University of Notre Dame Press.

Collier, Simon, and William F. Sater. 2004. A History of Chile, 1808-2002. 2nd ed. Cambridge: Cambridge University Press. http://ebooks. cambridge.org/ref/id/CBO97805II99II89.

CORFO. I965. Geografía Económica de Chile. Texto Refundido. Santiago, Chile: Editorial Universitaria.

Correa, Sofía, Consuelo Figueroa, Alfredo Jocelyn-Holt, Claudio Rolle, and Manuel Vicuña. 200I. Historia Del Siglo XX Chileno: Balance Paradojal. I. ed. Siglo XX Chileno 2. Santiago de Chile: Editorial Sudamericana. Crisp, Brian F., and Scott W. Desposato. 2004. "Constituency Building in Multimember Districts: Collusion or Conflict?" The Journal of Politics 66 (I): 136-56. https://doi.org/10.I046/j.I468-2508.2004.00145.x.

Dockendorff, Andrés. 2019. "When Do Legislators Respond to Their Constituencies in Party Controlled Assemblies? Evidence from Chile." Parliamentary Affairs, January. https://doi.org/ıo.I093/pa/gszoo2.

Domínguez, Jorge I., and Rafael Fernández de Castro, eds. 20Io. Contemporary U.S.-Latin American Relations: Cooperation or Conflict in the 21st Century? I. ed. Contemporary Inter-American Relations Series. New York, NY: Routledge.

Dunning, Thad. 2008. Crude Democracy: Natural Resource Wealth and Political Regimes. Cambridge Studies in Comparative Politics. New York: Cambridge University Press.

El Mercurio. 2003. "Libre Comercio: Agro Busca Frenar El TLC Con EEUU," April 23, 2003.

El Mercurio. - 2004. "Diputado Vilches: Fondos del royalty tienen que ir a regiones mineras | Emol.com," December 9, 2004.

Fenno, Richard F. I978. Home Style: House Members in Their Districts. Pearson College Division.

Fermandois, Joaquín, Jimena Bustos, and María José Schneuer. 2009. Historia Política Del Cobre En Chile. I. ed. Santiago: Ediciones Centro de Estudios Bicentenario.

Ffrench-Davis, Ricardo. 2002. "El Impacto de Las Exportaciones Sobre El 
Crecimiento En Chile." Revista de La CEPAL, no. 76: 143-6o.

Fukumoto, Kentaro, and Akitaka Matsuo. 20I5. "The Effects of Election Proximity on Participatory Shirking: The Staggered-Term Chamber as a Laboratory: Staggered-Term Chamber." Legislative Studies Quarterly 40 (4): 599-625. https://doi.org/IO.IIII/lsq.I2090.

Gamboa, Ricardo, and Sergio Y. Toro. 2018. "The Electoral Connection in Presidential Systems: Non-Legislative Actions inside the Chilean Congress." The Journal of Legislative Studies 24 (3): 249-7I. https:// doi.org/10.1080/13572334.2018.1516602.

Gardini, Gian Luca, and Peter Lambert, eds. 20II. Latin American Foreign Policies: Between Ideology and Pragmatism. Ist ed. New York: Palgrave Macmillan.

George, Alexander L., and Andrew Bennett. 2005. Case Studies and Theory Development in the Social Sciences. BCSIA Studies in International Security. Cambridge, Mass: MIT Press.

Gerring, John. 2004. "What Is a Case Study and What Is It Good For?" American Political Science Review 98 (02): 34I-54. https://doi. org/10.1017/So003055404001182.

Gourevitch, Peter Alexis. I986. Politics in Hard Times: Comparative Responses to International Economic Crises. Ithaca: Cornell University Press.

Haggard, Stephan. 1990. Pathways from the Periphery: The Politics of Growth in the Newly Industrializing Countries. Cornell University Press.

Herzer, Dierk, and Felicitas Nowak-Lehnmann D. 2006. "What Does Export Diversification Do for Growth? An Econometric Analysis." Applied Economics 38 (I5): I825-38. https://doi. org/10.1080/00036840500426983.

Katzenstein, Peter J. I985. Small States in World Markets: Industrial Policy in Europe. Cornell Studies in Political Economy. Ithaca, N.Y: Cornell University Press.

Kay, Cristobal. 2002. "Chile's Neoliberal Agrarian Transformation and the Peasantry." Journal of Agrarian Change 2 (4): 464-50I. https://doi. org/IO.IIII/I47I-0366.00043.

Lazarus, Jeffrey. 2009. "Party, Electoral Vulnerability, and Earmarks in the U.S. House of Representatives." The Journal of Politics 7I (3): I050-6I. https://doi.org/IO.IOI7/So022381609090872.

Leight, Jessica. 2008. "The Political Dynamics of Agricultural Liberalisation in the US-Chile Free Trade Agreement." Journal of Latin American Studies 40 (02). https://doi.org/IO.IOI7/So022216X08003970. 
Mares, David R., and Francisco Rojas Aravena. 200I. The United States and Chile: Coming in from the Cold. Contemporary Inter-American Relations. New York: Routledge.

Markoff, John, and Verónica Montecinos. I993. "The Ubiquitous Rise of Economists." Journal of Public Policy I3 (OI): 37-68. https://doi. org/Io.IoI7/SoI438I4Xooooo933.

Montecinos, Veronica. 2009. "Economics: The Chilean Story." In Economists in the Americas, edited by Veronica Montecinos and John Markoff. Edward Elgar Publishing. https://doi.org/I0.4337/9781849803465.0 oоIо.

Mora, Frank O., and Jeanne A. K. Hey, eds. 2003. Latin American and Caribbean Foreign Policy. Lanham, Md: Rowman \& Littlefield Publishers.

Moran, Theodore H. I974. Multinational Corporations and the Politics of Dependence: Copper in Chile. Princeton University Press.

Morandé, José. 2003. "The Invisible Hand and Contemporary Foreign Policy." In Latin American and Caribbean Foreign Policy, edited by Frank O. Mora and Jeanne A. K. Hey, 243-64. Lanham, Md: Rowman \& Littlefield Publishers.

Morgan, Jana. 20I8. "Political Decentralization and Party Decay in Latin America." Latin American Research Review 53 (March): I-I8. https:// doi.org/I0.25222/larr.255.

Muñoz, Heraldo, and Carlos Portales. I99r. Elusive Friendship: A Survey of USChilean Relations. Rienner.

Napoli, Enzo, and Patricio Navia. 2012. "La Segunda Es La Vencida: El Caso Del Royalty de 2004 y Del Impuesto Específico a La Gran Minería de 2005 En Chile." Gestión y Política Pública 2I: I4I-83.

Neuman, Stephanie G., ed. I998. International Relations Theory and the Third World. Ist ed. New York: St. Martin's Press.

Norris, Pippa.I997.“ThePuzzleofConstituencyService.” The JournalofLegislative Studies 3 (2): 29-49. https://doi.org/I0.1080/13572339708420508.

Oyarzún, Lorena. 20I3. "When Trade Policy Is Not Enough: Opportunities and Challenges for Chile's International Insertion." Journal of Iberian and Latin American Research I9 (2): 268-85. https://doi.org/I0.Io80 /13260219.2013.853357.

Pastor, Robert A. 200I. Exiting the Whirlpool: U.S. Foreign Policy toward Latin America and the Caribbean. 2nd. ed. Boulder, Colo: Westview Press.

Petras, James. I973. "Chile: Nationalization, Socioeconomic Change and Popular Participation." Studies in Comparative International 
Development 8 (I): 24-5I. https://doi.org/I0.1007/BF02809987.

Petras, James F., and Morris Morley. 1975. The United States and Chile: Imperialism and the Overthrow of the Allende Government. New York London: Monthly Review Pr.

Petras, James, and Maurice Zeitlin. I967. "Miners and Agrarian Radicalism." American Sociological Review, 578-86.

Pezzola, Anthony. 2006. "The Deep Roots of Trade Policy: How Subnational Interests Determine National Trade Policy." Doctoral, Seattle: University of Washington.

Pezzola. 2013. "States in the Customs House: Institutional Reforms and Structural Change in Mexican Trade Policy." International Studies Quarterly 57 (2): 34I-55. https://doi.org/IO.IIII/j.I4682478.2012.00755.x.

Pezzola. 20I7. "Trade Politics Is Local Politics: Subnational Interests and Commercial Policy in Argentina." Revista de Ciencia Política 37 (I): I2I-45. https://doi.org/10.4067/So718-090X2017000100006.

Porras, José Ignacio. 2003. "La Estrategia Chilena de Acuerdos Comerciales: Un Análisis Político.” 36. Comercio Internacional. Santiago de Chile: CEPAL. https://www.cepal.org/es/publicaciones/4376-la-estrategiachilena-acuerdos-comerciales-un-analisis-politico.

Puryear, Jeffrey. I994. Thinking Politics: Intellectuals and Democracy in Chile, 1973-1988. Baltimore: Johns Hopkins University Press.

Russell, Roberto, and Juan Gabriel Tokatlian. 20II. "Beyond Orthodoxy: Asserting Latin America's New Strategic Options Toward the United States." Latin American Politics and Society 53 (4): I27-46. https://doi. org/I0.IIII/j.I548-2456.2011.00136.x.

Russo, Federico. 20II. "The Constituency as a Focus of Representation: Studying the Italian Case through the Analysis of Parliamentary Questions." The Journal of Legislative Studies I7 (3): 290-30I. https:// doi.org/10.1080/13572334.20II.595122.

Schoultz, Lars. I998. Beneath the United States: A History of U.S. Policy toward Latin America. Cambridge, Mass: Harvard University Press.

Snyder, Jack L. I991. Myths of Empire: Domestic Politics and International Ambition. Ithaca, N.Y.: Cornell University Press.

Stein, Robert M., and Kenneth N. Bickers. I994. "Congressional Elections and the Pork Barrel." The Journal of Politics 56 (2): 377-99. https:// doi.org/10.2307/2132144.

Szary, Anne-Laure. I997. "Regiones Ganadoras y Regiones Perdedoras En El 
Retorno de La Democracia En Chile: Poderes Locales y Desequilibrios Territoriales." EURE 23: 59-78.

Trubowitz, Peter. 1998. Defining the National Interest: Conflict and Change in American Foreign Policy. American Politics and Political Economy. Chicago: University of Chicago Press.

Trubowitz. 20II. Politics and Strategy: Partisan Ambition and American Statecraft. Princeton Studies in International History and Politics. Princeton: Princeton University Press.

Tulchin, Joseph S., and Ralph H. Espach, eds. 200I. Latin America in the New International System. Boulder, Colo: Lynne Rienner Publishers.

Undurraga, Tomás. 20I4. "Rearticulación de grupos económicos y renovación ideológica del empresariado en Chile I975-20I2: la paradoja de la concentración." In Grupos económicos y mediana empresa familiar en América Latina, edited by Martín Zanatti Monsalve. Lima: Universidad del Pacífico.

Wilhelmy, Manfred. I979. "Hacia Un Análisis de La Política Exterior Chilena Contemporánea.” Estudios Internacionales I2 (48): 440-7I. https:// doi.org/I0.2307/41390965.

Wilhelmy, Manfred, and Roberto Durán. 2003. "Los Principales Rasgos de La Política Exterior Chilena Entre I973 y El 2000.” Revista de Ciencia Política (Santiago) 23: 273-86.

\begin{abstract}
What explains variation on Chile's foreign trade and investment policies toward the United States? While previous studies have underscored international and country-level factors, this work focuses on how subnational economic differences lead to conflicts that shape the country's policymaking. It examines Chile's history of commercial policies toward the U.S., focusing on critical events between I965 and 2005 , finding that foreign trade and investment policy conflicts develop along regional lines during democratic periods and on issues where subnational differences in export dependence are stronger.
\end{abstract}

\title{
KEYWORDS
}

Subnational Politics; Foreign Trade; Foreign Investment

Received on December 20, 2018

Approved on May 8, 2020 